\title{
THE ñMINGAò COMMUNITY PARTICIPATION FOR THE MAINTENANCE OF VERNACULAR HERITAGE BUILDINGS IN THE HISTORICAL CENTER OF CUENCA, ECUADOR
}

\author{
M. C. Achig-Balarezo ${ }^{1}$, A. Tenze ${ }^{1}$ \\ ${ }^{1}$ Universidad de Cuenca, Facultad de Arquitectura y Urbanismo, Av. 12 de abril y Agustín Cueva, Cuenca, Ecuador ï \\ (cecilia.achig@ucuenca.edu.ec, aliciatenze@yahoo.es)
}

Commission II, WG II/8

KEY WORDS: cultural heritage, community participation, preventive conservation, maintenance campaigns, Ecuador.

\begin{abstract}
:
The Latin-American cities declared by UNESCO World Heritage Sites display a problem of generalized deterioration of its vernacular or environmental architecture due to, among others, a lack of maintenance. This is aggravated by the existing legal vacuum in planning for its historical centers, resulting in irreversible losses in their heritage buildings. It is proposed to involve the community in the maintenance interventions to counteract the lack of maintenance and at the same time contribute to improve the level of livability and to create a collective awareness in the community about the care of its heritage. To achieve this goal, the university of Cuenca, has implemented the so-called ñmaintenance campaignsò, through which the preventive conservation phases proposed by ICOMOS (2003) are supported methodologically from a perspective that combines varied techniques (quantitative, qualitative), giving priority to operational workshops and collective construction of knowledge and action. The experience in the traditional đ́as Herreríasôstreet (case study), evidenced in a short period of time an improvement of the physical conditions of the buildings and of the quality of life of its residents, and furthermore motivated the long-term activation of comprehensive and inclusive conservation processes that lead to the valuation and preservation of heritage by all involved. The participation of the community in the whole process through a ñmingaò of multiple actors guarantees a successful intervention. This initiative could be successfully adapted to other heritage sites of similar characteristics.
\end{abstract}

\section{INTRODUCTION}

There are about 40 Latin-American historical cities declared by UNESCO World Heritage Sites (UNESCO, 2018). The conservation of monumental heritage buildings such as churches, museums and in general public buildings belonging to the state, are normally considered within the planning of these cities, however, minor or vernacular architecture is often unprotected. In fact, the lack of maintenance of this type of architecture, also known as environmental, is one of the main causes of deterioration and its consequent poor state of conservation (Jácome, Newspaper: ñEl Comercioò, 2018). The majority of these heritage buildings are built with earth or wood, which places them in a situation of high vulnerability, putting their integrity and heritage values at risk (Astudillo, et al, 2018).

In Europe, this predicament is being debated at a conceptual level and in some cases in a practical manner through preventive conservation (Van Balen \& Vandesande, 2013) (Stulens, 2002). The phrase ñprevention is better than cureò (Monumentenwacht Vlaanderen, 2018) is a statement coming from the world of medicine, which in the world of architecture and built heritage, emphasizes that the early identification of maintenance actions could reduce or prevent important interventions that put at risk the heritage and its integrity or that require in the future large sums of money (García, Cardoso \& Van Balen, 2015) (Van Balen \& Vandesande, 2013). This would especially affect minor or vernacular architecture, which without being of monumental character, constitutes a legacy that generates appropriation and identity in the communities.

On this matter, to encourage discussion, there are organizations and institutions at an international level such as the UNESCO chair of Preventive Conservation, Maintenance and Monitoring of Monuments and Sites (PRECOM ${ }^{3} \mathrm{OS}$ ), established in 2008, which promote conferences and debates around the concept of preventive conservation and sustainability (Van Balen \& Vandesande, 2013). One should also mention the successful experience of "Monumentenwacht", a non-governmental organization established in the Netherlands in 1973 and in Flanders in 1991, which aims to support owners and managers of heritage buildings to prevent deterioration through systematic and thorough monitoring by means of maintenance work (Stulens, 2002). In Latin America, some countries are integrated into a network of heritage cities, which try to come to agreements to protect their tangible and intangible assets (UNESCO, 2005).

In Ecuador about $95 \%$ of the inventoried heritage buildings are in the hands of private or religious owners (Rohn, 2018), which complicates, in certain manner, their maintenance and conservation. An interesting initiative is the incentive program ñget your house in orderò of the Metropolitan Heritage Institute of Quito (2008), through which micro credits are granted to owners with payment capacity, who are interested in the rehabilitation and improvement of their houses in heritage areas and buildings (Arias, 2016; Delgadillo, 2008). However, these organizations do not give a practical nor effective response to the deterioration and lack of maintenance experienced by historical cities in Latin America throughout their marginalized sectors, leaving minor heritage buildings vulnerable and in an unsustainable long-term state. For this reason it is necessary to find viable alternatives and at lower costs to support the owners, which in general are low-income families who do not have the economic nor technical capacity to invest in maintenance. Faced with this situation, the academia has remained on the sidelines

\footnotetext{
* Corresponding author
} 
and particularly the faculties of architecture of the universities have not included providing practical solutions as a priority.

The University of Cuenca, through the World Heritage City Project of the Faculty of Architecture, has been implementing Maintenance Campaigns for several years, based on the ICOMOS (1) preventive conservation methodology (ICOMOS, 2003) and guaranteeing the optimization of resources, by organizing the participation of various actors through a minga (2). Three main actors exist: the academia, who until now has assumed the role of leader and coordinator, the organizations and the community. This modality proposes to look for organizations as strategic allies (institutions, foundations, associations or companies) who together with the University give technical and financial support, in addition to seeking to achieve the greatest involvement of the community (Figure 1).

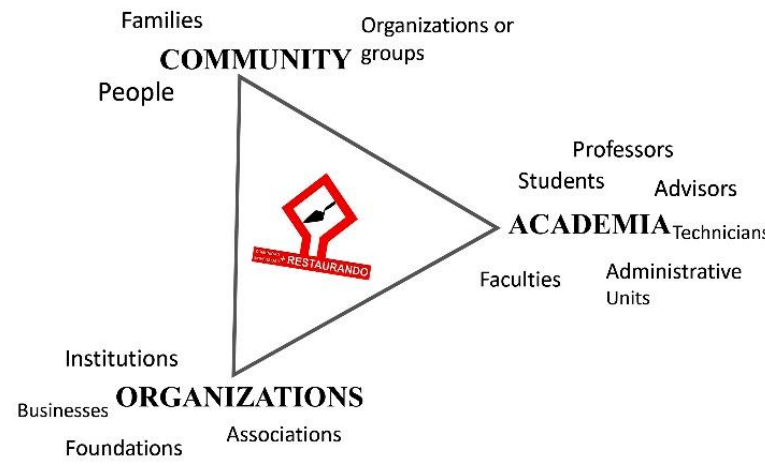

Figure 1. Main actors involved in maintenance campaigns. Source: Alicia Tenze, 2019

Two campaigns have been carried out in rural areas (Susudel houses in 2011 and Susudel cemetery in 2013) and one in the traditional neighborhood of San Roque, in the city of Cuenca in 2014. In these first three campaigns, the main objective was to realize maintenance actions of the physical parts of several heritage buildings (Cardoso, Achig-Balarezo \& Barsallo, 2017). However, in these campaigns the social component was not addressed in depth, which could be an influential factor in future decisions about continuing with the maintenance of vernacular heritage buildings. The objective of the present research is to understand the conservation and maintenance of heritage not only from an aesthetic or physical aspect, but from a more complete analysis that includes the social aspect directly related with the intangible dimension of heritage. As case study is taken the maintenance campaign undertaken in the year 2018 in one of the areas with the greatest heritage value of the city of Cuenca: đas Herreríasôstreet. This new intervention focused on the idea of conserving a building not only because it is heritage, but also to analyze other factors, which give it the character of a ñdevelopment resourceò, directly benefiting the community and its quality of life (Achig-Balarezo, et al, 2017).

(1) ICOMOS: International Council on Monuments and Sites

(2) The minga is defined as collective unpaid work for the common interest of the community. The minga (minka in the traditional Andes language Quechua) is a pre-Columbian tradition for purposes of social or reciprocal nature, currently being used in various Latin American countries, such as Colombia, Peru, Ecuador, Bolivia, Chile and Paraguay. In Europe exists an equivalent known as ñprocomunò. It can have different purposes, such as the building of a house or agricultural

\section{METHODOLOGY}

The maintenance campaign carried out in 20 heritage buildings in the ñLas Herreríasò street responds to a methodological process in which in each preventive conservation phase (ICOMOS, 2003): analysis, diagnosis, therapy and control, the approach of the participatory methodologies was integrated to emphasize the work with the network of actors (RedCIMAS, 2015), mainly the owners of the intervened buildings, in order to strengthen the trust between them, the internalization of the process and the awareness about the care and sustainability of heritage. In each of the phases, techniques of different research approaches were applied: quantitative (surveys, survey cards), to gather the countable aspects and to have a general idea of the issues; qualitative (interviews, tours, interactive workshops) to give prominence to people and groups and to collect their opinions in a more detailed manner; and participatory (reflection and collective construction workshops) to return the gathered information and to gain insight in the issues, supporting meetings between the participating actors. With regard to the actors, the academia refers to all of the people involved from the University of Cuenca, being 55 students (interns and volunteers), 4 thesis students, 6 professors, 15 professionals: architects, engineers and economists (9 specialists in heritage conservation) and administrative personnel. Within the organizations, the municipality of Cuenca was a strategic ally to complement the financing, the purchase of materials and the hiring of personnel, in addition it coordinated the participation of 17 organizations (institutions, associations, foundations, companies), who contributed with their competencies and resources to help develop the campaign. The participation of the community was important to complement the payment of the workers, the availability of toilets and the preparation of refreshments for the participants.

The maintenance of heritage buildings is a process that begins in the ANALYSIS phase, with the determination of the heritage values of the neighborhood and the buildings, as well as the manner in how the buildings to be intervened are going to be selected. In the DIAGNOSTIC phase, the state of conservation of the buildings is determined, through the use of damage registration cards, determining what actions and budgets are required to carry out their maintenance. These first two phases were carried out between March 2017 and April 2018 with students of the ñHeritage Conservationò course of the faculty of Architecture and Urbanism of the University of Cuenca being in charge, supported by interns and thesis students, with the counsel and advice of professors and heritage conservation specialists. In the next phase, THERAPY, the activities of the execution of the campaign are recorded on a daily basis through a control book. This phase was carried out between May and August 2018 with all of the members of the World Heritage City project joining the intervention team. The CONTROL AND MONITORING phase started in September 2018, during which surveys with regard to the state of conservation were carried out.

Simultaneously, the evaluation of the process (before, during, after) and its impact on the social, cultural, economic and environmental dynamics of the intervened area was carried out.

activities. The minga does not need obligations nor incentives for its execution, since all of its participants are beneficiaries alike. It is a form of communal work, in which all work together for something beneficial to all participants, and where the participants contribute with their labor in exchange for collective benefits (Ferrari, 2004; Cachiguango, 2006; García et al., 2015; Wikipedia, 2018). 
Several of the tools used during this process are explained next. During the first phases of the campaign (ANALYSIS and DIAGNOSIS), the objective was to find the ex-ante expectations (ex-ante) of the campaign. Three types of surveys were used: a) to the owners of the buildings to be intervened, $b$ ) to the residents and persons who own a business in the ñLas Herreríasò street, c) to the passersby who circulate through the r̃Las Herreríasòstreet. During the execution phase of the campaign (THERAPY), a survey was designed in order to know the opinion of the various actors on issues related to the management, the process and the execution of the works. These surveys were conducted with the owners of the intervened buildings, tenants and residents of the ñLas Herreríasò street, military personnel, workers, members of the World Heritage City project and participating students. Simultaneously, interviews were conducted with the various participating actors and several participatory evaluation workshops were held with the community to monitor the impact and the coherence of the objectives with respect to the functioning of the intervening teams. This process helped to give feedback to the activities and ensure compliance with the general objectives of the maintenance campaign. Having completed the maintenance work (start of the CONTROL phase), the same tools were applied to gather the ex-post assessments and to evaluate the social, economic, cultural and environmental impact of the campaign on the intervened area, and to emphasize the knowledge gathered, which will be used to improve future maintenance campaigns.

Table 1 summarizes the techniques and actors employed during the different phases of the ñHerreríasò maintenance campaign. On the left are shown the employed techniques during the preventive conservation process, while on the right the techniques of the evaluation process are shown.

\begin{tabular}{|c|c|c|c|c|}
\hline \multirow[b]{2}{*}{ PHASES } & \multicolumn{2}{|c|}{ MAINTENANCE IMPLEMENTATION } & \multicolumn{2}{|c|}{ PROCESS EVALUATION } \\
\hline & TECHNIQUES & ACTORS & TECHNIQUES & ACTORS \\
\hline ANALYSIS & Socioeconomic records & Community & & \\
\hline \multirow{5}{*}{ DIAGNOSIS } & Damage record & Community & Surveys $* *$ & Community \\
\hline & $\begin{array}{l}\text { Meetings with the } \\
\text { community and } \\
\text { organizations }\end{array}$ & $\begin{array}{l}\text { Academy } \\
\text { Community } \\
\text { Organizations }\end{array}$ & SWOT Matrix & Academy \\
\hline & & & & \\
\hline & Walks & $\begin{array}{l}\text { Academy } \\
\text { Community }\end{array}$ & Workshops & Community \\
\hline & $\begin{array}{l}\text { Participatory } \\
\text { workshops }\end{array}$ & $\begin{array}{l}\text { Academy } \\
\text { Community }\end{array}$ & & \\
\hline \multirow{3}{*}{ THERAPY } & Control book* & $\begin{array}{l}\text { Academy } \\
\text { Community }\end{array}$ & Surveys & Community \\
\hline & $\begin{array}{l}\text { Technical coordination } \\
\text { meetings }\end{array}$ & Academy & $\begin{array}{l}\text { Evaluation } \\
\text { meeting }\end{array}$ & Academy \\
\hline & $\begin{array}{l}\text { Meetings with the } \\
\text { community and } \\
\text { organizations }\end{array}$ & $\begin{array}{l}\text { Academy } \\
\text { Community } \\
\text { Organizations }\end{array}$ & Surveys & $\begin{array}{l}\text { Academy } \\
\text { Organizations }\end{array}$ \\
\hline \multirow{4}{*}{ CONTROL } & Maintenance booklets & Community & Surveys** & $\begin{array}{l}\text { Community } \\
\text { Organization }\end{array}$ \\
\hline & Damage record & Community & Interviews** & Community \\
\hline & Monitoring record & $\begin{array}{l}\text { Academy } \\
\text { Organizations }\end{array}$ & $\begin{array}{l}\text { Participatory } \\
\text { workshop** }\end{array}$ & Academy \\
\hline & Owner's report & Community & $\begin{array}{l}\text { Diagram of } \\
\text { communication } \\
\text { and relationship } \\
\text { between actors }\end{array}$ & $\begin{array}{l}\text { Academy } \\
\text { Community }\end{array}$ \\
\hline
\end{tabular}

Table 1. Employed techniques during the preventive conservation phases. Source (Tenze, et al, 2019)

In grey are shown the results that have been analyzed and respond to the objectives of this research. Some of the objectives to be

(3) Enchancleado: a traditional ceiling made of earth and straw, and supported by a wooden structure. (Cardoso, Quizhpe \& Achig, 2018) achieved with the ñHerreríasò maintenance campaign were a) to start a maintenance process of the vernacular heritage buildings (*) and b) to analyze how the campaign could improve the quality of life, the social cohesion in the El Vergel neighborhood and awaken an interest within the community for the conservation of heritage, which was achieved through an evaluation of the process $(* *)$

\section{RESULTS AND DISCUSSION}

\subsection{Items carried out and perception of the community about the impact of the campaign}

In this section are presented the results of the components: maintenance implementation $(*)$ and process evaluation $(* *)$ (Table 1). According to the records of the control book, of the 20 buildings intervened during the THERAPY phase, in 15 buildings comprehensive maintenance of facades, roofs and urgent works were carried out, and in the remaining 5 buildings minor maintenance of facades was done. Below are the results of the main items with their corresponding quantities (Table 2):

\begin{tabular}{lcr}
\hline Items & Units & \multicolumn{1}{c}{ Total } \\
\hline Repaired roof structures & $\mathrm{u}$. & 17 \\
Recovered tiled roofs & $\mathrm{m} 2$ & 1465 \\
Maintenance of doors & $\mathrm{m} 2$ & 71 \\
Maintenance of windows & $\mathrm{m} 2$ & 16 \\
Maintenance of balconies & $\mathrm{m} 2$ & 3 \\
Maintenance of stairs & $\mathrm{m} 2$ & 2 \\
Painting of facades (maintenance) & $\mathrm{m} 2$ & 1056 \\
Intervened ceilings & $\mathrm{m} 2$ & 315 \\
Placing and replacement of channels and & $\mathrm{m}$ & 289 \\
downspouts & & \\
\hline
\end{tabular}

Table 2. Total quantities of the main items carried out during the ñHerreríasò Maintenance Campaign during May and Agosto of 2018.

Table 2 shows that the most significant interventions were on roofs and facades. These results confirm the fulfillment of the general objective of the campaign with regard to the undertaking of urgent maintenance actions of roofs and facades in heritage buildings. With regard to that, several clarifications that derive from the conducted interviews indicate that some traditional construction systems, such as the enchancleado (3), that were in a bad state, could not be rescued due to economic factors, since these required specialized labor. However, it is necessary to emphasize that in 5 intervened buildings, evidence of this constructive system was left in place. In relation to the contribution of the campaign to the improvement of the quality of life and social cohesion in the neighborhood, from participating professors and technicians there is a perception that this was fulfilled: ñThrough the campaign it was possible to generate this cohesion between tenants, owners and the neighborhood in generalò (technician 1), ñThe objective of social assistance to the community was metò (professor 1), ñYes, because a heritage has been protected and at this moment the neighborhood has another appearance, another spritò (professor 2).

The results of the surveys with the owners of the intervened buildings allows to compare their perception before and after the 
campaign (Table 3). Regarding their expectations of the maintenance campaign, the most mentioned expectations were: improvement of the physical appearance of the buildings, improvement of the integration of the neighborhood, economic improvement and improvement of their quality of life. Some neighbors expressed their sentiments in different ways: ñf I would live a thousand years, a thousand years I would thank those who made it possible for my house to be so beautifulò (neighbor 1, Figure 2), ñThis restauration initiative has not been seen in years. Honestly, I am happy with the resultò(University Agenda, August 2018, Figure 3).

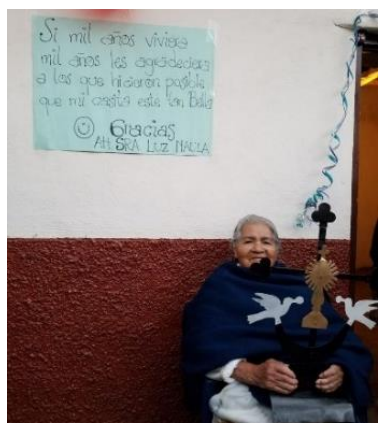

Figure 2. Luz Naula on the day the maintenance campaign interventions finished. Source: Carolina Martinez, 2018.

The expectations of the Project team also materialized in two pedagogical objectives. On the one hand, to generate knowledge about heritage conservation through a practical exercise, which had a general assessment of fulfillment: ñfrom a research point of view, all of the knowledge gathered through the campaign is also important; in terms of constructive systems, relations with people, either with the institutions, the owners or the team itselfò (technician 2). On the other hand, to create awareness among the owners about the value of the heritage building that they own. An objective, which according to the interviews was partially fulfilled. In fact, during the execution of the campaign, it was found that some owners proposed to eliminate elements of heritage value. This is confirmed by the testimony of a professor: ñWe lacked trainingé everything that is heritage and that is maintenance.ò (Professor 3). This factor is related to the management of the requirements of the owners, where most comments point to better information with regard to the scope of the intervention, which would moderate the ownersô expectations. However, it seems that from the interaction and through the execution process it was possible to raise awareness about this issue: ñThe owners, many of them with an extraordinary attitude, finally succeeded to understand what it is that we can do, what it is that we should doò (professor 4).

Considering the evaluation of the impacts in the community, the different tools were oriented to contrast before (ex-ante) expectation with after (ex-post) assessments in the four areas of development. Table 1 highlights the surveys that were subject of this analysis during the DIAGNOSIS (before) and CONTROL phase (after). Additionally, this component was enriched with the results of the interviews with the owners and the opinions of the academic team in a participatory evaluation workshop. Before and after the campaign a survey was conducted with respectively 13 and 15 owners out of a total of 20 owners. The reason that not all owners were surveyed is that not all owners live in the neighborhood or because some of the owners were not willing to participate in the surveys.
Table 3 shows the results in relation to the economic, social and cultural aspects. With regard to the economic aspect, to the question: ñDo you think that during the campaign your business will be affected?ò, $31 \%$ of the owners before the campaign answered YES, while after the campaign this slightly reduced to $27 \%$. This result allows us to infer that during the campaign the majority of the ownersô businesses were not affected by the campaign and probably received benefits due to the large number of participants.

ñé created a benefit to the businesses, since on the one hand they could prevent damage to the rented properties and on the other hand refresh the image of their premisesò (student 1).

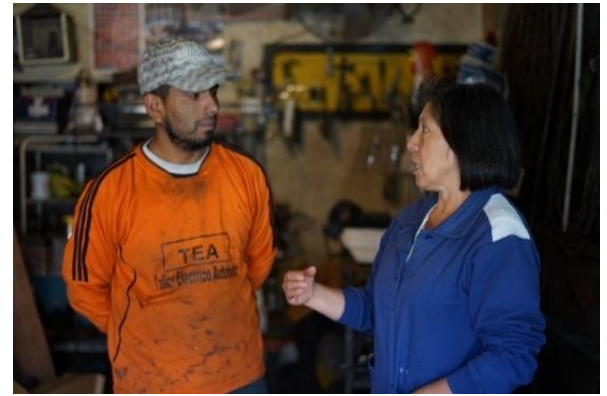

Figure 3. Etelvina Gallegos, neighbor. Source: University Agenda, August 2018

With regard to the social aspect, the relation between neighbors shows a significant difference before and after the campaign (54\% before and $73 \%$ after), which indicates an improvement in the integration of the neighborhood.

ñé the minga always awakens values... is a meeting place and in this case favored the meetings between neighbors, between institutions, between organizations and the neighborhood, etcé ò (technician 2).

With regard to the cultural aspect, to the question: ñDo you know the ancestral traditions practiced in this neighborhood?ò, the majority answered YES, with the before and after results being very similar (above 69\%). When asked: ñDo you think that investing public money in conserving heritage is a waste?ò, the majority answered NO (above $80 \%$ ).

ñé surely the people that live in the ñLas Herreríasò Street view their heritage in a different way, surely they also feel part of this heritageò (student 2). The responses regarding active participation in the campaign were very diverse, in relation to what was understood by "actively". Precisely, activities such as food preparation, availability of bathrooms (and its cleaning) or monetary contribution were considered as active participation in the Campaign.

With regard to the environmental aspect, it was possible to confirm that within the expectations the safety issue was not considered a priority. However, the owners at the end of the campaign expressed the improvements obtained at the neighborhood level, especially regarding accessibility, safety and cleanliness of the buildings.

ñ think that in general the street is more accessible, safer and has a better environmentò (student 3 ).

The results of the surveys with people that live or that have a business in the ñLas Herreríasò street, but who did not participate in the maintenance campaign, are very similar to the answers of the owners of the buildings who did participate in the campaign. In this case, the sample was 18 people before and 45 people after the campaign. 
The International Annals of the Photogrammetry, Remote Sensing and Spatial Information Sciences, Volume IV-2/W6, 2019 27th CIPA International Symposium "Documenting the past for a better future", 1-5 September 2019, Ávila, Spain

\begin{tabular}{|c|c|c|c|c|c|}
\hline \multirow[t]{2}{*}{ QUESTION } & \multicolumn{2}{|c|}{ BEFORE } & \multirow[t]{2}{*}{ QUESTION } & \multicolumn{2}{|c|}{ AFTER } \\
\hline & $\mathrm{n}$ & $\%$ & & $\mathrm{n}$ & $\%$ \\
\hline Do you live in the El Vergel neighborhood, Las & & & Do you live in the El Vergel neighborhood, Las & & \\
\hline Herrerías street? & & & Herrerías street? & & \\
\hline NO & 5 & $38 \%$ & NO & 7 & $47 \%$ \\
\hline YES & 8 & $62 \%$ & YES & 7 & $47 \%$ \\
\hline No answer & & & No answer & 1 & $7 \%$ \\
\hline EXPECTATIONS & & & EXPECTATIONS & & \\
\hline What do you expect from the campaign? & & & The Campaign allowed: & & \\
\hline Benefits to handicapped & 2 & $6 \%$ & Benefits to handicapped & & $0 \%$ \\
\hline Promote ancestral practices & 2 & $6 \%$ & Promote ancestral practices & 4 & $9 \%$ \\
\hline Safer & 3 & $9 \%$ & Safer & 5 & $11 \%$ \\
\hline Economic improvement & 5 & $15 \%$ & Economic improvement & 8 & $17 \%$ \\
\hline Improvement in the physical aspect of the buildings & 8 & $24 \%$ & Improvement in the physical aspect of the buildings & 13 & $28 \%$ \\
\hline Improvement in the integration of the neighborhood & 4 & $12 \%$ & Improvement in the integration of the neighborhood & 7 & $15 \%$ \\
\hline Improvement in the quality of life & 6 & $18 \%$ & Improvement in the quality of life & 9 & $20 \%$ \\
\hline Preservation of traditional art & 1 & $3 \%$ & Preservation of traditional art & & $0 \%$ \\
\hline Safety & 3 & $9 \%$ & Safety & & $0 \%$ \\
\hline ECONOMIC ASPECTS & & & ECONOMIC ASPECTS & & \\
\hline Do you have any business other than rental in Las & & & Do you have any business other than rental in Las & & \\
\hline Herrerías street? & & & Herrerías street? & & \\
\hline NO & 6 & $46 \%$ & NO & 7 & $47 \%$ \\
\hline YES & 5 & $38 \%$ & YES & 4 & $27 \%$ \\
\hline No answer & 2 & $15 \%$ & No answer & 4 & $27 \%$ \\
\hline $\begin{array}{l}\text { Do you think that during the campaign your business } \\
\text { will be affected? }\end{array}$ & & & Was your business affected? & & \\
\hline NO & 3 & $23 \%$ & NO & & $0 \%$ \\
\hline YES & 4 & $31 \%$ & YES & 4 & $27 \%$ \\
\hline No answer & 6 & $46 \%$ & No answer & 11 & $73 \%$ \\
\hline SOCIAL ASPECTS & & & SOCIAL ASPECTS & & \\
\hline $\begin{array}{l}\text { How was your relationship with your neighbors } \\
\text { before the campaign? }\end{array}$ & & & How is it now? & & \\
\hline Good & 7 & $54 \%$ & Good & 11 & $73 \%$ \\
\hline Bad & & $0 \%$ & Bad & 1 & $7 \%$ \\
\hline I did not know them & 1 & $8 \%$ & I did not know them & & $0 \%$ \\
\hline I do not know them & 1 & $8 \%$ & I do not know them & & $0 \%$ \\
\hline Regular & 3 & $23 \%$ & Regular & 3 & $20 \%$ \\
\hline No answer & 1 & $8 \%$ & No answer & & $0 \%$ \\
\hline CULTURAL ASPECTS & & & CULTURAL ASPECTS & & \\
\hline $\begin{array}{l}\text { Do you think that investing public money in } \\
\text { conserving 'heritage' is a waste? }\end{array}$ & & & $\begin{array}{l}\text { Do you think that investing public money in } \\
\text { conserving 'heritage' is a waste? }\end{array}$ & & \\
\hline NO & 11 & $85 \%$ & NO & 12 & $80 \%$ \\
\hline YES & & $0 \%$ & YES & 2 & $13 \%$ \\
\hline No answer & 2 & $15 \%$ & No answer & 1 & $7 \%$ \\
\hline $\begin{array}{l}\text { Do you know the ancestral traditions practiced in } \\
\text { this neighborhood? }\end{array}$ & & & $\begin{array}{l}\text { Do you know the ancestral traditions practiced in this } \\
\text { neighborhood? }\end{array}$ & & \\
\hline NO & 3 & $23 \%$ & NO & 4 & $27 \%$ \\
\hline YES & 9 & $69 \%$ & YES & 11 & $73 \%$ \\
\hline No answer & 1 & $8 \%$ & No answer & & $0 \%$ \\
\hline $\begin{array}{l}\text { Would you like to participate actively in the } \\
\text { execution of the campaign? }\end{array}$ & & & Did you participa te actively? & & \\
\hline NO & & $0 \%$ & NO & 6 & $40 \%$ \\
\hline YES & 11 & $85 \%$ & YES & 9 & $60 \%$ \\
\hline No answer & 2 & $15 \%$ & No answer & & $0 \%$ \\
\hline
\end{tabular}

Table 3.

Comparison of the ownersôperception in relation to the economic, social and cultural aspects. Sample size of 13 (before) and 15 (after) the maintenance campaign. Source: The authors. 


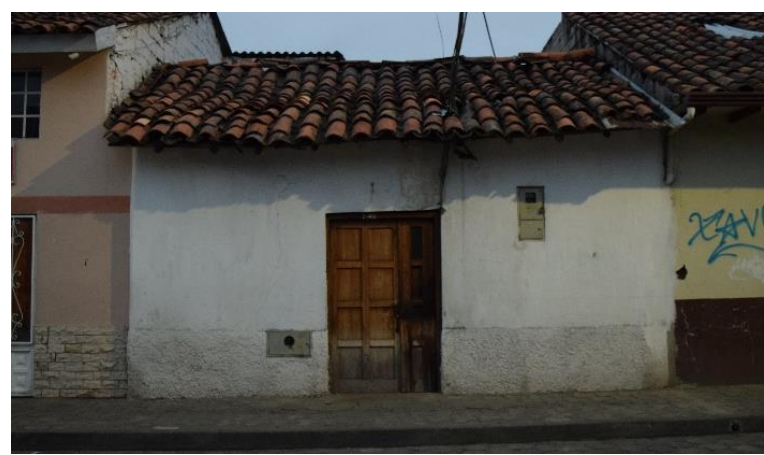

Figure 4. Before the Herrerías Maintenance Campaign Source: City Preservation Management project.

A similar campaign carried out in the San Roque neighborhood did not consider other actors of the neighborhood who could have enriched the proposal and unleashed a participatory process (Achig, et al, 2017). This situation improved in the r̃Herreríasò campaign. In fact, when measuring the impacts, the perception of several actors was considered, such as: residents of the ñLas Herreríasò street who did not participate in the campaign, passersby, technicians, representatives of collaborating institutions and organizations as well as the team of the University of Cuenca. The processing and analysis of all this information, due to its extent and complexity, could be object of another research. Without a doubt, the enlargement of the network of actors who took part in the ñHerreríasò campaign is important to ensure its sustainability.

3.2 Contributing to a collective leading role in the maintenance of vernacular heritage buildings

The ñHerreríasò Campaign sought to influence the leading role, especially of the owners, considering that in previous campaigns, as for example in San Roque, they had a passive role, limited to observation and approval of the works of their particular building (Achig, et al, 2017) In the ñHerreríasò campaign this was achieved by turning the owners into collaborators of the planning and execution processes: ñWorking hand in hand with them, I believe is a very interesting learning experience for the people. To see that their contribution is important, from the refreshments, to giving permission to enteré ò (professor 5) (Figure 5)

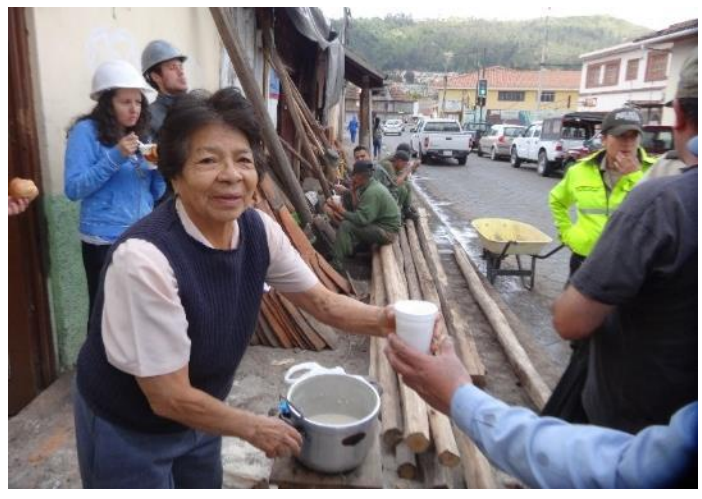

Figure 5. Neighbor, Mrs. Zoila Naula, giving refreshments to the workers. The Herrerías Maintenance Campaign. Source: Maria Cecilia Achig, 2018

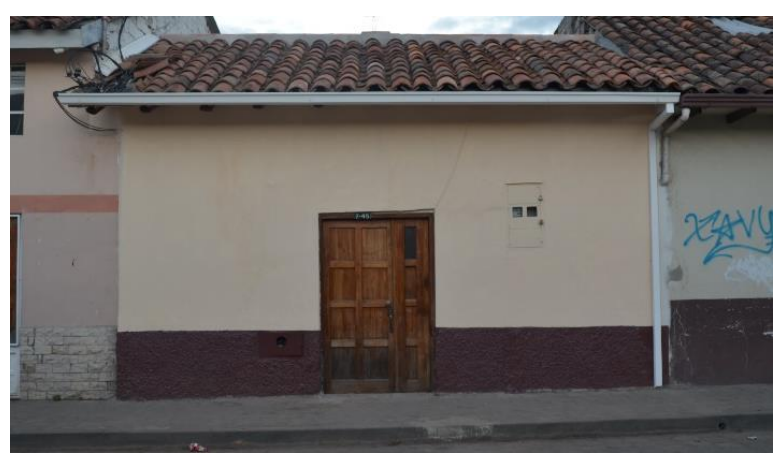

Figure 6. After the Herrerías Maintenance Campaign Source: City Preservation Management project.

This style of research identifies networks of actors to develop a listening process, mainly to give and receive feedback and produce collective reflection meetings (RedCIMAS, 2015). The space created by the maintenance campaign favored recognition among stakeholders, especially among neighbors themselves, who interacted in various programmed activities. As a result, in the process synergies were generated directed at strengthening the bonds of trust and collaboration between them.

ñThe minga is always a learning experience, people can see what it is that the organizations do, how they do it, understand how they work, what it is that they can doò (professor 6)

Indeed, the meetings between the community and other involved stakeholders had the purpose of building this collective leading role, which at the same time allowed to move from ñcampaign projectòto ñmaintenance processò:

ñI think thaté they also helped to build this collective spirit. This willingness to participate in something that goes beyond their own personal interest. This willingness to transform the neighborhood is evident in meetingsé But yes, they help to build a collective condition of this processò (professor 7) (Figure 4 \& 6). Several interviews revealed the lack of awareness among the owners about the values and conservation of heritage buildings. Therefore, it is important to complement the educational contribution of the process itself with a teaching and systematic information program before and during the campaign, about the value of the heritage that is being intervened and the type of technical solutions that are being planned for its conservation. For that very reason, it is necessary to strengthen the involvement of the owners, both in the meetings or workshops as well as in the unforeseen circumstances during the campaign, which in the Herrerías campaign, mostly had to do with family or tenant conflicts.

All in all, the learning experiences, which in addition to being collective, came from a process that triggered the interrelationship between stakeholders and in this process there is also the change of perspective about the meaning and identity of the neighborhood:

ñCampaigns tend to be quite emotional, and that is what motivates one to conservation, to be a neighborhood again. The meaning of neighborhood has been lost a lot in our city, so it motivates one to that, to conserve, to take care, to be a neighborhood again, to share with people, to improve the street environment, to improve the social aspect of that neighborhoodò (expert in heritage conservation 1) Research is currently underway to make these experiences sustainable in the future, with the participation of all stakeholders, from the initial draft of the project to the monitoring phases after the intervention. 


\section{CONCLUSIONS}

The minga of multiple actors or stakeholders has allowed the maintenance of 20 vernacular heritage buildings, with the consequent quality of life improvement of those living there. Furthermore, it is possible to ensure that the participation of the community during the different phases of the maintenance campaign, being planning (analysis, diagnosis), execution (therapy) and evaluation (control), is a guarantee for a successful intervention. Encouraging community participation, raising awareness about the tangible and intangible values of the heritage architecture in which they live is one of the challenges within these initiatives.

In the Herrerías Maintenance Campaign, the participation of the community was proposed as part of a multiple stakeholderôs minga, not only to guarantee the optimization of resources in the restoration of built heritage, as in the previous three campaigns, but also to foster the networks that act in the neighborhood with a shared leading role. The initiative of the university was based on providing its resources at the service of the people, in this case, for the conservation of heritage buildings in a state of high vulnerability. The implementation of the Campaign fostered the collaboration and involvement of other entities, both public as well as private, and of the neighboring community, mainly the owners of the buildings to be intervened.

Through a participatory investigation-action process, it was sought to enhance each phase of the technical process and to carry out a shared work from the formulation of the project among the various stakeholders, with the community being one of the most important to consider. This is because in the community resides the cultural value that gives meaning and significance to heritage, not only tangible, such as the buildings, but also intangible, an essential part of its historical tradition. It is proposed that in future campaigns the training of the community about the value of their heritage buildings is being emphasized and prioritized during the entire maintenance campaign

\section{ACKNOWLEDGEMENTS}

A special gratitude to the neighbors of the El Vergel neighborhood and óThe Herreríasôstreet, to the members of the team of the University of Cuenca, the municipality and to all others who participated and made the Herrerías Maintenance Campaign possible.

\section{REFERENCES}

Achig-Balarezo, M. C., Vázquez, L., Barsallo, M. G., Briones, J. C. \& Amaya, J. 2017. Strategies for the management of built heritage linked to Maintenance and monitoring. Case study of the San Roque Neighborhood, Cuenca, Ecuador. Carleton University. CIPA OTAWA 2017, evento ISPRS International Society for Photogrammetry and Remote sensing. (CIPA) Downloaded https://www.int-arch-photogramm-remote-sensspatial-inf-sci.net/XLII-2-W5/755/2017/ (11 November 2018)

Arias, A. 2016. Quito aprendiendo desde la experiencia. Planure. Digital journal. N. 8. Downloaded: https://www.planur-e.es/articulos/ver/patrimonio-vivo-quitoaprendiendo-desde-la-experiencia-
Astudillo, S., Achig-Balarezo, M. C., Barsallo, G. \& Cardoso, F. 2018. ñThe university work on the Wolrd Heritage City Project, intervention models for the rescue and preventive conservation of earth-based architectureò, artículo publicado en las memorias del congreso Terra Education III 2018, realizado en Grenoble en junio de 2018. TERRA Education se organiza con el auspicio de la Cátedra UNESCO Chair: ñArquitectura de tierra, construcción de culturas y desarrollo sostenibleò y en el marco del Programa de arquitectura de tierra del patrimonio mundial (WHEAP).

Cachiguango, L. 2006. La sabiduría andina en la fiesta y el trabajo. Cuaderno de investigación en Cultura y Tecnología Andina. N. 23. IECTA, Chile, 2006.

Cardoso, F., Achig-Balarezo, M. C. \& Barsallo, M. G. 2017. Preventive conservation tools in southern Ecuador. In Journal of Cultural Heritage Management and Sustainable Development. Downloaded:

http://www.emeraldinsight.com/eprint/FHU6TRRFKR7SSWCF ZUPM/full

https://www.emeraldinsight.com/doi/pdfplus/10.1108/JCHMSD $-06-2017-0033$

Cardoso, F., Quizhpe, M. A. \& Achig-Balarezo, M. C. 2018. ñValoración de la arquitectura en tierra en Cuenca, Ecuador, como herramienta para su conservaciónò. 18 SIACOT: Seminario Iberoamericano de Arquitectura y Construcción con Tierra. La Antigua Guatemala. Universidad de San Carlos de Guatemala, del 22 al 25 de octubre de 2018. Artículo evaluado por un Comité Científico y publicado en las memorias del evento. 412 ï 421. Downloaded:

https://www.dropbox.com/s/s3cmwpx911wxydk/Libro\%20de \% 20memorias $\% 2018 \% \mathrm{C} 2 \%$ B0\%20SIACOT.pdf?dl=0

Delgadillo, V. 2008. Mejoramiento habitacional en las áreas urbanas centrales de América Latina: del combate de tugurios a la Rehabilitación habitacional progresiva. Revista invi Vol. 23, Núm. 64. Downloaded:

http://revistainvi.uchile.cl/index.php/INVI/article/view/444/943

Ferraro, E. 2004. Reciprocidad, don y deuda. Relaciones y formar de intercambio en los Andes ecuatorianos. La comunidad de Pesillo. FLACSO, Sede Ecuador. Ediciones Abya-Yala, Quito Ecuador.

García, G,. Cardoso, F,. \& Van Balen, K. 2015. ñThe Challenges of Preventive Conservation theory applied to Susudel, Ecuador.ò in Reflections on Preventive Conservation Theories and Practices. by the Raymond Lemaire International Centre for Conservation. Leuven-Belgium, 117-129

Jácome, E. 2018. Tomado del Diario: ñEl Comercioò artículo: ñ143 casas están abandonadas en el Centro Histórico de Quitoò publicado el 19 de enero de 2018. Downloaded:

https://www.elcomercio.com/actualidad/casas-abandonadascentro-historico-quito.html

ICOMOS charter - principles for the analysis, conservation and structural restoration of architectural heritage (2003) Art. 1.6 Downloaded (http://www.icomos.org/charters/structures_e.pdf (23 November 2018)

Monumentenwacht Vlaanderen 2018. (Downloaded http://www.monumentenwacht.be/over-monumentenwacht last consulted 25/11/2018) Beter voorkomen dan genezen, traducido significa: prevenir es mejor que curar. 
The International Annals of the Photogrammetry, Remote Sensing and Spatial Information Sciences, Volume IV-2/W6, 2019 27th CIPA International Symposium "Documenting the past for a better future", 1-5 September 2019, Ávila, Spain

RedCIMAS 2015. ñMetodologías participativas, sociopraxis para la creatividad socialò, Ed. Dextra, Madrid.

Rohn, I. 2018. Las Políticas Públicas para la Gestión del Patrimonio en el Ecuador. Ponencia presentada en el evento. ñJornadas de Reflexión sobre la enseñanza de la protección del patrimonio en la Universidad de Cuencaòel 4 de octubre de 2018.

Stulens, A.2002. ñMonument Watch in Flanders: an outlineò, in Stulens, A. (Ed), First International Monumentenwacht Conference 2000, Amsterdam, 2002:15

Tenze, A., Amaya, J. \& García, G. 2019. Informe de evaluación de la Campaña de Mantenimiento de las edificaciones patrimoniales de la calle Las Herrería. Proyecto Ciudad Patrimonio Mundial, Facultad de Arquitectura de la Universidad de Cuenca.

UNESCO World Heritage List. Downloaded: https://whc.unesco.org/en/list (23 November 2018)

UNESCO, 2005. Convenio para la creación de la organización latinoamericana y del caribe para la conservación de los Centros Históricos (OLACCHI). Downloaded:

http://www.unesco.org/culture/natlaws/media/pdf/ecuador/ecua dor_convorglatincar_11_spaorof (25 November 2018)

University Agenda, August 2018 Edición 69. Downloaded: https://www.ucuenca.edu.ec/servicios/agenda-universitaria

Van Balen, K. \& Vandesande, A. 2013. Reflections on Preventive Conservation, Maintenance and Monitoring of Monuments and Sites, by the PRECOM ${ }^{3}$ OS UNESCO Chair. Editorial ACCO. Leuven-Belgium.

Wikipedia: Concepto de Minka. Downloaded: https://es.wikipedia.org/wiki/Minka (15 February 2019) 